\title{
ANALISIS TINGKAT RISIKO TSUNAMI TERHADAP BANGUNAN HUNIAN DI DESA ULEE LHEUE KECAMATAN MEURAXA KOTA BANDA ACEH
}

\author{
Siti Nidia Isnin \\ e-mail: sitinidiaisnin@gmail.com
}

\begin{abstract}
On 26th of December 2004, a giant wave 'Tsunami' triggered by enourmous earthquake of 9 richter scale in magnitude located in Indian Ocean, to the west of Sumatra Island. This study is focusing on' Tsunami Risk Level on Residential Buildings in Ulee Lheue Village, Meuraxa Sub-district, Banda Aceh'. This study is aiming to determine the level of the Tsunami potential danger, to determine the level of vulnerability of the Tsunami on Residential Buildings and to determine the level of the Tsunami risk on residential buildings. Determining the level of the Tsunami potential danger is based on coastal line inundation modelling which are $1 \mathrm{~m}, 2 \mathrm{~m}, 5 \mathrm{~m}, 15 \mathrm{~m}$ and $30 \mathrm{~m}$. This study considered the residential buildings as element at risk. The level of Tsunami vulnerability on residential buildings is based on relative vulnerbility index (RVI) of PTVA-3 model and its modifications. The level of the Tsunami risk on residential buildings is based on risk classes. Tsunami risk classes on residential buildings using PTVA model are not different with modification model. Inundation scenario of $1 \mathrm{~m}, 2 \mathrm{~m}$, and $5 \mathrm{~m}$, tsunami risk class on residential building is catogorized into Class I and inundation scenario of $15 \mathrm{~m}$ and $30 \mathrm{~m}$ is categorized into class II. The differance of the models is lied on the nominal of potential loss.
\end{abstract}

Keyword: Risk, Tsunami, Residential Buidlings, Ule Lheue Village

\begin{abstract}
ABSTRAK
Tsunami yang terjadi di Aceh pada 26 Desember 2004 disebabkan oleh gempa di dasar laut dengan kekuatan $9 \mathrm{Sr}$ di Samudra Hindia sebelah barat Pulau Sumatra. Penelitian ini melakukan pengkajian Tingkat Risiko Tsunami Terhadap Bangunan Hunian Di Desa Ulee Lheue Kecamatan Meuraxa Kota Banda Aceh. Tujuan penelitian adalah menentukan tingkat potensi bahaya tsunami, menentukan tingkat kerentanan tsunami terhadap bangunan hunian, dan menentukan tingkat risiko tsunami terhadap bangunan hunian. Penentuan tingkat potensi bahaya tsunami berdasarkan pemodelan genangan dari garis pantai, yaitu $1 \mathrm{~m}, 2 \mathrm{~m}, 5 \mathrm{~m}, 15 \mathrm{~m}$, dan $30 \mathrm{~m}$. Penelitian ini mempertimbangkan bangunan hunian sebagai elemen at risk. Tingkat kerentanan tsunami terhadapa bangunan hunian didasarkan pada indek kerentanan relatif $(\mathrm{RVI})$ dari model PTVA-3 dan modifikasi. Tingkat risiko tsunami terhadap bangunan hunian berdasarkan dari kelas risiko. Kelas risiko tsunami terhadap bangunan hunian dengan menggunakan model PTVA tidak berbeda dengan model modifikasi. Skenario genangan $1 \mathrm{~m}, 2 \mathrm{~m}$, dan $5 \mathrm{~m}$, kelas risiko tsunami terhadap bangunan huniannya berada di kelas 1 , dan skenario genangan $15 \mathrm{~m}$ dan $30 \mathrm{~m}$ berada pada kelas 2 . Perbedaan kedua model ini adalah pada nilai nominal kerugiannya.
\end{abstract}


Kata Kunci: Risiko, Tsunami, Bangunan Hunian, Desa Ulee Lheue

\section{Pendahuluan}

Aceh merupakan provinsi paling barat di Indonesia yang merupakan bagian dari Pulau Sumatra. Bagian Barat Pulau Sumatra terdapat zona subduksi antara Lempeng Indo-Australia dengan Lempeng Eurasia. Lempeng Indo-Australia menunjam ke bawah Lempeng Eurasia karena pengaruh gravitasi. Gerakan ini menyebabkan adanya patahan. Patahan tersebut menyebabkan gempa berkekuatan 9 SR yang disusul oleh tsunami pada tanggal 26 Desember 2004 (Cassidy, 2015). Menurut (Hadmoko, et al., 2007), Tsunami yang terjadi di Aceh diakibatkan oleh gempa dengan magnitude9,00 SR di Samudra Hindia sebelah barat Pulau Sumatra.

Data dari Dinas Prasarana Wilayah dan Pemukiman Propinsi Aceh tahun 2005 di dalam penelitian (Zulkarnaini, 2007) menunjukkan bahwa Meuraxa termasuk salah satu kecamatan di Kota Banda Aceh yang memiliki dampak paling parah akibat tsunami, untuk lebih jelasnya dapt dilihat pada Tabel 1.1 Kecamatan ini mengalami korban jiwa terbanyak yaitu 25.561 jiwa baik yang meninggal maupun hilang. Kerusakan rumah terparah yaitu sejumlah 4.949 rumah, dengan rincian 4.766 rusak berat, 156 rusak sedang dan 27 rusak ringan.

Risiko bencana menurut UndangUndang No. 24 Tahun 2007 adalah potensi kerugian yang ditimbulkan oleh bencana di suatu kawasan dalam kurun waktu tertentu seperti kematian, luka, sakit, jiwa terancam, hilangnya rasa aman, mengungsi, kerusakan atau kehilangan harta, dan gangguan kegiatan masyarakat. Berdasarkan definisi-definisi tersebut, risiko bencana menjadi suatu perhatian di dalam manajemen bencana. Analisis tingkat risiko menjadi hal yang penting dalam perencanaan pembangunan baik secara fisik maupun non fisik. Risiko selalu terkait dengan ketersediaan informasi sehingga probabilitas kejadian dan besarnya dampak bisa diperhitungkan (Bastian, 2006). Pengukuran tingkat risiko bencana di dalam (Mardiatno dkk, 2012) diukur dengan menggunakan dua faktor, yaitu tingkat bahaya dan tingkat kerentanan.

Penelitian tingkat risiko tsunami di Desa Ulee Lheue Kecamatan Meuraxa Kota Banda Aceh difokuskan pada kerentanan fisik dengan elemen yang berisiko adalah bangunan hunian. Bangunan hunian menjadi isu yang paling penting dalam penanganan pascabencana, karena bangunan hunian menjadi kebutuhan primer bagi manusia. Bangunan hunian menjadi tempat berlindung manusia dari panas dan hujan, serta dapat memberikan rasa aman. Pengkajian tingkat risiko bencana akan memberikan infomasi lokasi yang memiliki tingkat risiko yang tinggi maupun rendah, yang berguna untuk penanggulangan bencana.

Berdasarkan pada latar belakang dan permasalahan yang telah dikemukakan, maka disusun tujuan penelitian sebagai berikut: 
1.Menentukan tingkat bahaya tsunami di Desa Ulee Lheue

2.Menentukan tingkat kerentanan tsunami terhadap bangunan hunian di Desa Ulee Lheue

3.Menentukan tingkat risiko Tsunami bangunan hunian di Desa Ulee Lheue

\section{Tingkat Bahaya Di Desa Ulee Lheue}

Data yang dibutuhkan untuk menghitung probabilitas tsunami dalam 100 tahun membutuhkan data gempa yang menyebabkan tsunami selama 100 tahun.
Sumber data dari usgs dan BMKG. Perhitungan probabilitas gempa yang menyebabkan tsunami dalam penelitian ini menggunakan probabilitas marginal. Probabilitas marginal merupakan jenis probabilitas yang tidak menggunakan syarat atau batasan. Perhitungan probabilitas marginal dengan menggunakan rumus: Probabilitas $=$ jumlah kejadian/ periode. Berdasarkan data pada Tabel 2.1, probabilitas kejadian gempa yang menyebabkan tsunami selama 107 tahun adalah 0,04.

Tabel 1. Data Historis Kejadian Gempa Dan Tsunami Di Aceh

\begin{tabular}{|c|c|c|c|}
\hline Tanggal Kejadian & Lokasi & $\begin{array}{c}\text { Kekuatan } \\
\text { Gempa (Mw) }\end{array}$ & Keterangan \\
\hline 1907 & Simeulu & - & Tsunami \\
\hline 02/04/1964 & Banda Aceh & 5,2 & \\
\hline 12/04/1967 & Lhokseumawe & 6,1 & Tsunami \\
\hline 04/04/1983 & Banda Aceh & 6,6 & \\
\hline 02/11/2002 & Simeulu & 6,5 & \\
\hline 26/12/2004 & Nad & 9 & Tsunami \\
\hline 26/02/2005 & Simeulu & 6,8 & Tsunami \\
\hline 20/02/2008 & $\begin{array}{l}\text { Simeulu } \\
\text { Barat Daya Banda }\end{array}$ & 7,4 & \\
\hline $11 / 04 / 2012$ & Aceh & 8,6 & \\
\hline $16 / 02 / 2013$ & Barat Banda Aceh & 4,8 & \\
\hline $10 / 04 / 2013$ & $\begin{array}{l}\text { Barat Banda Aceh } \\
\text { Barat Daya Banda }\end{array}$ & 4,7 & \\
\hline $19 / 05 / 2013$ & Aceh & 4,6 & \\
\hline $16 / 06 / 2013$ & $\begin{array}{l}\text { Barat Banda Aceh } \\
\text { Barat Laut Banda }\end{array}$ & 4,7 & \\
\hline 07/11/2014 & $\begin{array}{l}\text { Aceh } \\
\text { Barat Laut Banda }\end{array}$ & 5,5 & \\
\hline $11 / 11 / 2014$ & Aceh & 4,9 & \\
\hline 23/11/2014 & Barat Banda Aceh & 5,5 & \\
\hline
\end{tabular}

(Sumber: USGS dan BMKG)

Potensi bahaya ditentukan dari meter, skenario ketinggian genangan masing-masing skenario, yaitu 2 meter, skenario ketinggian skenario ketinggian genangan 1 genangan 5 meter, skenario 
ketinggian genangan 15 meter, dan skenario ketinggian genangan 30 meter. Peta potensi bahaya seperti yang disajikan pada gambar 2.1, 2.2, 2.3, 2.4, dan 2.5 menggunakan dasar dari peta penggunaan lahan dan kemiringan lereng. Dari data penggunaan lahan dikonversikan untuk mendapat indeks kekasaran permukaan. koefisien kekasaran menunjukkan kemampuan air lolos untuk masuk kedaratan. Pemodelan genangan tsunami dapat dilakukan dengan menggunakan model dari Hawke's Bay. Model ini mempertembingkan ketinggian gelombang dari pantai, koefisien kekasaran permukaan dan kemiringan lereng (Berryman, 2006). Model Hawke's Bay memiliki persamaan seperti berikut:

$\mathrm{H}_{\text {Loss }}=\left(167 . \mathrm{n}^{2} / \mathrm{H}_{0}{ }^{1 / 3}\right)+5 . \operatorname{Sin} \mathrm{S}$

Keterangan:
$\mathrm{H}_{\text {Loss }}=$ kehilngan ketinggian gelombang permeter dari jarak genangan

$\mathrm{H}_{0} \quad$ = tinggi gelombang dari pantai $\mathrm{n}=$ koefisien kekasaran permukaan

$\mathrm{s} \quad=$ lereng

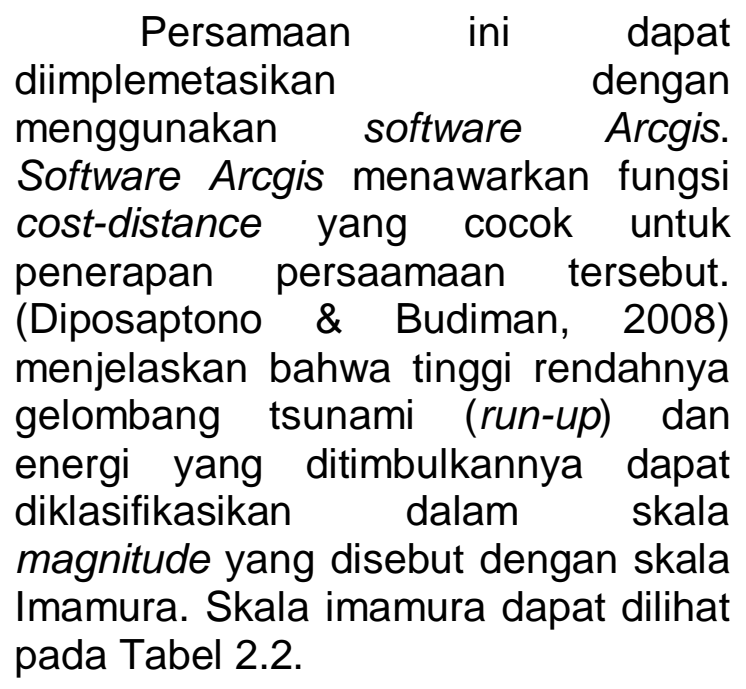

Tabel 2. Skala Immamura -lida

\begin{tabular}{lcl}
\hline No & Skala Immamura-lida & \multicolumn{1}{c}{ Klasifikasi } \\
\hline 1 & -1 & Sunami dengan run-up $<50 \mathrm{~cm}$ di daerah pantai \\
2 & 0 & Tsunami dengan run-up $1 \mathrm{~m}$ \\
3 & 1 & Tsunami dengan run-up $>2 \mathrm{~m}$ \\
4 & 2 & Tsunami dengan run-up $4-6 \mathrm{~m}$ \\
5 & 3 & Tsunami dengan run-up $10-20 \mathrm{~m}$ \\
6 & 4 & Tsunami dengan run-up $>30 \mathrm{~m}$ \\
\hline
\end{tabular}

Sumber: (Diposaptono \& Budiman, 2008)

Secara spasial tingkat bahaya dikelaskan menjadi lima kelas, yaitu kawasan yang tergenang kurang dari ketiggian 2 meter termasuk kelas sangat rendah, kawasan yang tergenang dari ketinggian 2-5 meter termasuk kelas yang rendah, kawasan yang tergenang dari ketinggian 5-15 meter termasuk kelas yang sedang, kawasan yang tergenang dari ketinggian 15-30 meter termasuk kelas tinggi, dan kawasan yang tergenang lebih dari ketinggian 30 meter termasuk kelas yang sangat tinggi. Kelas potensi bahaya ditentukan dari masing-masing skenario, yaitu skenario ketinggian genangan 1 meter, skenario ketinggian genangan 2 meter, skenario ketinggian genangan 5 meter, skenario ketinggian genangan 15 meter, dan skenario ketinggian 
genangan 30 meter. Rincian luas Ulee Lheue dapat dilihat pada tabel 3 daerah dan kelas bahaya di Desa

\section{Tabel 3. Luas daerah berdasarkan tingkat bahaya}

\begin{tabular}{|c|c|c|c|c|c|c|}
\hline \multirow{3}{*}{$\begin{array}{l}\text { Skenario } \\
\text { Genangan } \\
\text { (m) }\end{array}$} & \multicolumn{5}{|c|}{ uas Wialayah Bahaya $\left(\mathrm{m}^{2}\right)$} & \multirow[b]{3}{*}{ Jumlah } \\
\hline & $<2 m$ & $2-5 m$ & $5-15 m$ & $15-30 \mathrm{~m}$ & $>30 \mathrm{~m}$ & \\
\hline & $\begin{array}{l}\text { Sangat } \\
\text { rendah }\end{array}$ & Rendah & Sedang & Tinggi & $\begin{array}{c}\text { Sangat } \\
\text { tinggi }\end{array}$ & \\
\hline 1,00 & $16.122,65$ & - & - & - & - & $16.122,65$ \\
\hline 2,00 & $27.513,59$ & - & - & - & - & $27.513,59$ \\
\hline 5,00 & $5.613,80$ & $30.298,70$ & - & - & - & $35.912,50$ \\
\hline 15,00 & $1.747,85$ & $4.829,72$ & $59.709,87$ & - & - & $66.287,43$ \\
\hline 30,00 & - & - & $1.274,13$ & $66.306,49$ & - & $67.580,62$ \\
\hline
\end{tabular}

2. Tingkat Kerentanan Bangunan Hunian Di Desa Ulee Lheue

Penilaian tingkat kerentanan mengunkan model ptva. Model PTVA3 dikembangkan untuk memberikan pengukuran kerentanan bangunan akibat tsunami. Menurut (Dall'Osso dkk,2009) hasil dari pengukuran dengan menggunakn model PTVA3 adalah indek kerentanan relatif atau $\mathrm{RVI}$ dari setiap bangunan. nilai RVI bangunan dihitung berdasarkan pembobotan dua komponen, yaitu kerentanan yang berhubungan dengan daya dukung bangunan (SV) dan kerentanan bangunan oleh karena adanya kontak bangunan dengan air (WV). Variabel untuk mengukur daya dukung bangunan meliputi atribut dari struktur bangunan (Bv), derajat proteksi (Prot) yang tersedia untuk bangunan,kedalaman genangan air / eksposur (Ex) pada lokasi bangunan berdiri. Variabel untuk mengukur kontak bangunan dengan air adalah tinggi rumah yang tergenang oleh tsunami (Dall'Osso dkk, 2009), seperti yang disajikan pada tabel 3.1. Adapun persamaan model RVI adalah sebagi berikut:

$\mathrm{RVI}=2 / 3(\mathrm{SV})+1 / 3(\mathrm{WV})$

$\mathrm{SV}=(\mathrm{BV}) \times($ Prot $)$

Bv $(-1+1)=1 / 423(100 . s+80 . m+63 . g$

$+60 . f+51 . m o+46 . s o+23 . p c)$

so :bentuk dari orientasi banguna

mo :objek bergerak

$\mathrm{s} \quad$ : jumlah lantai

$\mathrm{m} \quad$ : material bangunan dan teknik konstruksi

g : hidrodinamisasi lantai dasar

$f \quad$ :fondasi

pc : pemeliharaan bangunan

Prot $(0+1)=1 / 301\left(100\right.$. Prot $_{b w}+73$ Prot $\mathrm{Sw}_{\mathrm{w}}+73$ prot $_{\mathrm{nb}}+55$ Prot $\left._{\mathrm{w}}\right)$

Prot $_{\text {bw }}$ : baris bangunan

Prot $_{\text {sw }}$ :keberadan dinding laut

Prot $_{n b}$ :hambatan alamiah

Prot $_{w}$ :keberadaan dinding bata disekitar

$\mathrm{WV}=$ (tingkat inundasi/jumlah total tingkatan) 
Tabel 3.1 Skor RVI Untuk Setiap Bangunan

\begin{tabular}{|c|c|c|c|c|c|}
\hline RVI (1-5) & $1-1,8$ & $1,8-2,6$ & $2,6-3,4$ & $3,4-4,2$ & $4,2-5$ \\
\hline $\begin{array}{l}\text { Deskripsi tingkat } \\
\text { kerentanan relatif }\end{array}$ & $\begin{array}{l}\text { Sangat } \\
\text { rendah }\end{array}$ & Rendah & Sedang & Tinggi & $\begin{array}{l}\text { Sangat } \\
\text { tinggi }\end{array}$ \\
\hline \multicolumn{6}{|c|}{$\mathrm{RVI}=(2 / 3) \mathrm{X}(\mathrm{SV})+(1 / 3) \mathrm{X}(\mathrm{WV}) \ldots . . \mathrm{Pers} .3$} \\
\hline $\begin{array}{l}\text { SV (asli) } \\
\text { SV (terskalakan) }\end{array}$ & $\begin{array}{l}1-25 \\
1\end{array}$ & $\begin{array}{l}25-50 \\
2\end{array}$ & $\begin{array}{l}50-75 \\
3\end{array}$ & $\begin{array}{l}75-100 \\
4\end{array}$ & $\begin{array}{l}100-125 \\
5\end{array}$ \\
\hline \multicolumn{6}{|c|}{$\mathrm{SV}=(\mathrm{Bv}) \times(\mathrm{Ex}) \times($ Prot $) \ldots$. Pers. 4} \\
\hline $\begin{array}{l}\text { Bv (asli) } \\
\text { Bv (terskalakan) } \\
\text { Prot (asli) } \\
\text { Prot (terskalakan) } \\
\text { Ex (asli) } \\
\text { Ex (Terskalakan) }\end{array}$ & $\begin{array}{l}-1 \text { s.d }-0,6 \\
1 \\
0-0,2 \\
1 \\
0-1 \mathrm{~m} \\
1\end{array}$ & $\begin{array}{l}-0,6 \text { s.d }-0,2 \\
2 \\
0,2-0,4 \\
2 \\
1-2 \mathrm{~m} \\
2\end{array}$ & $\begin{array}{ll}-0,2 & \text { s.d } \\
0,2 & \\
3 & \\
0,4-0,6 & \\
3 & \\
2-3 \mathrm{~m} & \\
3 & \\
\end{array}$ & $\begin{array}{l}0,2 \quad \text { s.d } \\
0,6 \\
4 \\
0,6-0,8 \\
4 \\
3-4 \mathrm{~m} \\
4\end{array}$ & $\begin{array}{l}0,6 \quad \text { s.d } \\
1 \\
5 \\
0,8-1 \\
5 \\
>4 \mathrm{~m} \\
5\end{array}$ \\
\hline \multicolumn{6}{|c|}{ WV $=($ tingkat inundasi/jumlah total tingkatan) $\ldots$ pers. 5} \\
\hline $\begin{array}{l}\text { WV (asli) } \\
\text { WV (terskalakan) }\end{array}$ & $\begin{array}{l}0-0,2 \\
1\end{array}$ & $\begin{array}{l}0,2-0,4 \\
2\end{array}$ & $\begin{array}{l}0,4-0,6 \\
3\end{array}$ & $\begin{array}{l}0,6-0,8 \\
4\end{array}$ & $\begin{array}{l}0,8-1 \\
5\end{array}$ \\
\hline
\end{tabular}

(Sumber: Dall'Osso dkk, 2000)

Berdasarkan perhitungan dapat diketahui kelas dari atribut masing-masing bangunan hunian di Desa Ulee Lheue seperti yang disajikan pada tabel 3.2. Terdapat 164 bangunan hunian yang berada dikelas3, 133 banguan hunian dikelas 4, dan 3 banguanan dikelas 5 . Bangunan didesa Ulee Lheue paling banyak berada dikelas 3, karena beberapa hal yang mempengaruhi adalah jumlah lantai bangunan di Desa Ulee Lheue berlantai 1 , fondasi yang dangkal dan hidrodianmisasi bangunan yang tertutup dan sedikit jelndela. Ketiga atribut tersebut padahal adalah atribut yang Terpenting daripada atribut yang lainnya.

Tabel 3.2 Kelas BV model PTVA

\begin{tabular}{|c|c|}
\hline $\begin{array}{c}\text { Kelas } \\
\text { Bv }\end{array}$ & $\begin{array}{c}\text { Jumlah } \\
\text { Bangunan }\end{array}$ \\
\hline 3 & 164 \\
\hline 4 & 133 \\
\hline 5 & 3 \\
\hline Jumlah & 300 \\
\hline
\end{tabular}


Proteksi memiliki fungsi sebagai sehingga berada di kelas 3, kelas 4 dan pelindung bangunan. Proteksi dapat kelas 5 . Ada 50 bangunan yang berada di berupa hal yang alamiah ataupun buatan manusia. Hal alamiah seperti pohonpohonan dan yang buatan berupa bangunan seperti dinding laut. Tingkat proteksi seperti yang disajikan pada Tabel 3.3 di Desa Ulee Lhueu terhadap bangunan hunian termasuk rendah,

kelas 3, 164 bangunan yang berada di keas 4 dan 86 bangunan dikelas 5 . Penyebab rendahnya tingkat proteksi di Desa Ulee Lheue yaitu tidak adanya perlindung pantai dan juga banyak bangunan hunian yang tidak memiliki dinding bata disekitar bangunan.

Tabel 3.33 Kelas Proteksi

\begin{tabular}{|c|c|c|}
\hline $\begin{array}{l}\text { Kelas } \\
\text { Proteksi }\end{array}$ & $\begin{array}{c}\text { Jumlah } \\
\text { Bangunan }\end{array}$ & Persentase \\
\hline Kelas 3 & 50 & 17 \\
\hline Kelas 4 & 164 & 55 \\
\hline Kelas 5 & 86 & 29 \\
\hline Total & 300 & 100 \\
\hline
\end{tabular}

Eksposur merupakan tingkat berada di kelas 1. Skenrio ketinggian kerentana bangunan terhadap model gelombang $5 \mathrm{~m}$, telah ada bangunan genangan tsunami. Semakin tinggi yang tergenang. Kelas eskposurnya genangan tsunami terhadap Bangunan hunian maka akan semakin besar pula kerusakan yang ditimbulkan. Ketinggian genangan tsunami didapatkan dari pemodelan skenario genangan. Tabel 3.4 menyajikan kelas ekposur terhadap masing-masing skenario genangan. Skenario ketinggian gelomang $1 \mathrm{~m}$, bangunan hunian berada pada kelas 1 , belum ada bangunan yang tergenang. Skenario ketinggian gelombang $2 \mathrm{~m}$, sama halnya dengan skenario $1 \mathrm{~m}$, belum ada bangunan hunian yang tergenang, sehingga semua bangunan hunian terhadap bangunan yang tergenang telah beragam. Terdapat 301 bangunan hunian yang berada di kelas 1, 3 banguan dikelas 2 dan 2 bangunan dikelas 4 . Skenario ketinggian gelombang $15 \mathrm{~m}$ seluruh bangunan hunian telah tergenang. Bangunan yang berada dikelas 4 hanya 2 bangunan dan 288 bangunan hunian berada dikelas 5 . Sama halnya dengan skenario gelombang $15 \mathrm{~m}$, skenario gelombang $30 \mathrm{~m}$, terdapat 2 bangunan dikelas 4 dan 288 bangunan dikelas 5 . 
Tabel 3.4. Kelas Eksposur

\begin{tabular}{|c|c|c|c|c|c|}
\hline Skenario & Kelas 1 & Kelas 2 & Kelas 3 & Kelas 4 & Kelas 5 \\
\hline $1 \mathrm{~m}$ & 286 & 14 & - & - & - \\
\hline $2 \mathrm{~m}$ & 290 & 10 & - & - & - \\
\hline $5 \mathrm{~m}$ & 232 & 9 & 26 & 30 & 3 \\
\hline $15 \mathrm{~m}$ & 9 & 2 & 4 & 3 & 282 \\
\hline $30 \mathrm{~m}$ & - & - & - & - & 300 \\
\hline
\end{tabular}

SV murni dengan menggunakan model PTVA memiliki kelas kerentanan dari kelas 1 sampai kelas 4 . Berdasarkan dari masing-masing skenario ketinggian gelombangang tingkat SV juga berbedabeda. Tabel 3.5 menyajikan tingkat SV untuk masing-masing skenario.

Pada skenario ketinggian gelombang $1 \mathrm{~m}$, tingkat SV memiliki kelas 1 dan 2. Terdapat 282 bangunan hunian yang berada di kelas 1 dan 18 rumah yang berada di kelas 2. Pada skenario ketinggian gelombang $2 \mathrm{~m}$, jumlah kelas sama halnya dengan skenario $1 \mathrm{~m}$. Jumlah bangunan di kelas 1 adalah 287 bangunan dan 13 bangunan pada kelas 2 . Skenario empat kelas untuk tingkat SV. Kelas 1 terdapat 234 bangunan hunian, kelas 2 terdapat 26 bangunan hunian, kelas 3 terdapat 24 bangunann hunian dan kelas 4 terdapat 16 bangunan hunian. Skenario $15 \mathrm{~m}$, ada 12 bangunan pada kelas 1,20 banguna pada kelas 2, 147 bangunan pada kelas 3 dan 113 bangunan pada kelas 4 . Skenario terakhir adalah skenario $30 \mathrm{~m}$, memiliki tiga kelas yaitu kelas 2, kelas 3 dan kelas 4 . Jumlah bangunan di kelas 2 adalah 41 bangunan, kelas 2 terdapat 149 bangunan dan kelas 4 terdapat 120 bangunan.

Tabel 3.5 Kelas SV Model PTVA

\begin{tabular}{|c|c|c|c|c|c|}
\hline Skenario & Kelas 1 & Kelas 2 & Kelas 3 & Kelas 4 & Kelas 5 \\
\hline $1 \mathrm{~m}$ & 282 & 18 & - & - & - \\
\hline $2 \mathrm{~m}$ & 287 & 13 & - & - & - \\
\hline $5 \mathrm{~m}$ & 234 & 26 & 24 & 16 & - \\
\hline $15 \mathrm{~m}$ & 12 & 28 & 147 & 113 & - \\
\hline $30 \mathrm{~m}$ & - & 31 & 149 & 120 & - \\
\hline
\end{tabular}

pada tabel 3.6. Skanario ketinggian

Perhitungan WV berdasarkan gelombang 1 dan 2 meter semua masing-masing skenario ketinggian bangunan hunian memiliki kelas 1. Pada gelombang yang telah dibuat, yaitu ada skenario ketinggian gelombang $5 \mathrm{~m}$ yang lima skenario genangan. Perhitungan WV terdapat tiga kelas yaitu kelas 1, 3 dan 5 . dengan meilihat berapa jumlah lantai Jumlah bangunan terbanyak terdapat bangunan hunian yang terendam oleh pada kelas 1. Skenario ketinggian tsunami. Kelas pada masing-masing gelombang $15 \mathrm{~m}$ dan $30 \mathrm{~m}$ semua skenario ketinggian gelombang tidak bangunan berada pada kelas 5 .

terlalu bervariatif seperti yang disajikan 
Tabel 3.6 Kelas WV

\begin{tabular}{|c|c|c|c|c|c|}
\hline Skenario & Kelas 1 & Kelas 2 & Kelas 3 & Kelas 4 & Kelas 5 \\
\hline $1 \mathrm{~m}$ & 300 & - & - & - & - \\
\hline $2 \mathrm{~m}$ & 300 & - & - & - & - \\
\hline $5 \mathrm{~m}$ & 291 & - & 5 & - & 10 \\
\hline $15 \mathrm{~m}$ & - & - & - & - & 300 \\
\hline $30 \mathrm{~m}$ & - & - & - & - & 300 \\
\hline
\end{tabular}

hanya terdapat 3 bangunan hunian.

Skenario ketinggian gelombang 1 Skenario ketinggian gelombang $15 \mathrm{~m}$, $\mathrm{m}$, seluruh bangunan hunian berada mayoritas bangunan hunian berada dikelas sangat rendah. Skenario dikelas sangat tinggi yaitu 195 bangunan ketinggian gelombang $2 \mathrm{~m}$, seluruh hunian. Kelas rendah sebanyak 12 bangunan hunian juga berada dikelas bangunan hunian. Begitu pula pada sangat rendah. Hal ini disebabkan oleh nilai SV dari setiap bangunan juga berada dikelas yang rendah, yaitu 1 atau 2. Pada skenario ketinggian gelombang $5 \mathrm{~m}, 15 \mathrm{~m}$ dan $30 \mathrm{~m}$, kelas RVI sangat bervariasi. Skenario ketinggian gelombang $5 \mathrm{~m}$ Sebagian besar bangunan hunia berada dikelas sangat rendah yaitu 243 bangunan hunian. Sisanya berada dikelas rendah, sedang dan tinggi. Pada kelas tinggi

skenario 30 , jumlah bangunan terbanyak terdapat pada kelas sangat tinggi yaitu sebanyak 199 bangunan hunian dan hanya 2 bangunan hunian yang berada dikelas rendah. Rinciannya hasil secara tabular dapat dilihat pada tabel 3.7 dan secara spasial dapat dilihat pada gambar $3.1,3.2,3.3,3.4$ dan 3.5.

Tabel 3.7 Kelas RVI model PTVA

\begin{tabular}{|l|c|r|r|r|l|}
\hline Skenaria & $\begin{array}{l}\text { Sangat } \\
\text { rendah }\end{array}$ & Rendah & Sedang & Tinggi & $\begin{array}{l}\text { Sangat } \\
\text { tinggi }\end{array}$ \\
\hline $1 \mathrm{~m}$ & 300 & - & - & - & - \\
\hline $2 \mathrm{~m}$ & 300 & - & & - & - \\
\hline $5 \mathrm{~m}$ & 243 & 31 & 23 & 3 & - \\
\hline $15 \mathrm{~m}$ & - & 12 & 21 & 72 & 159 \\
\hline $30 \mathrm{~m}$ & - & 2 & 22 & 77 & 199 \\
\hline
\end{tabular}




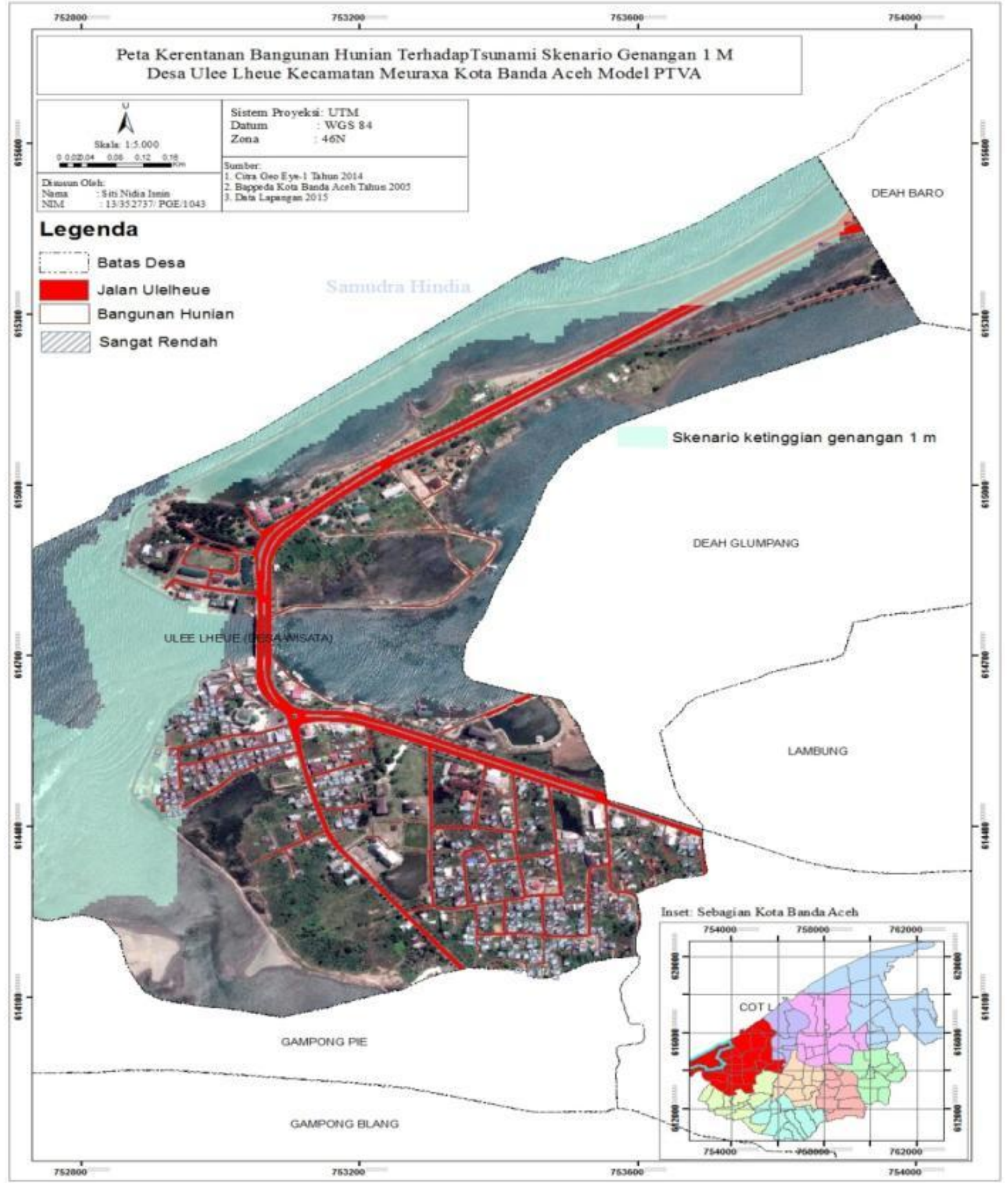

Gambar 3.1 Peta Kerentanan Bangunan Hunian Terhadap Tsunami Skenario Genangan 1m Model PTVA 


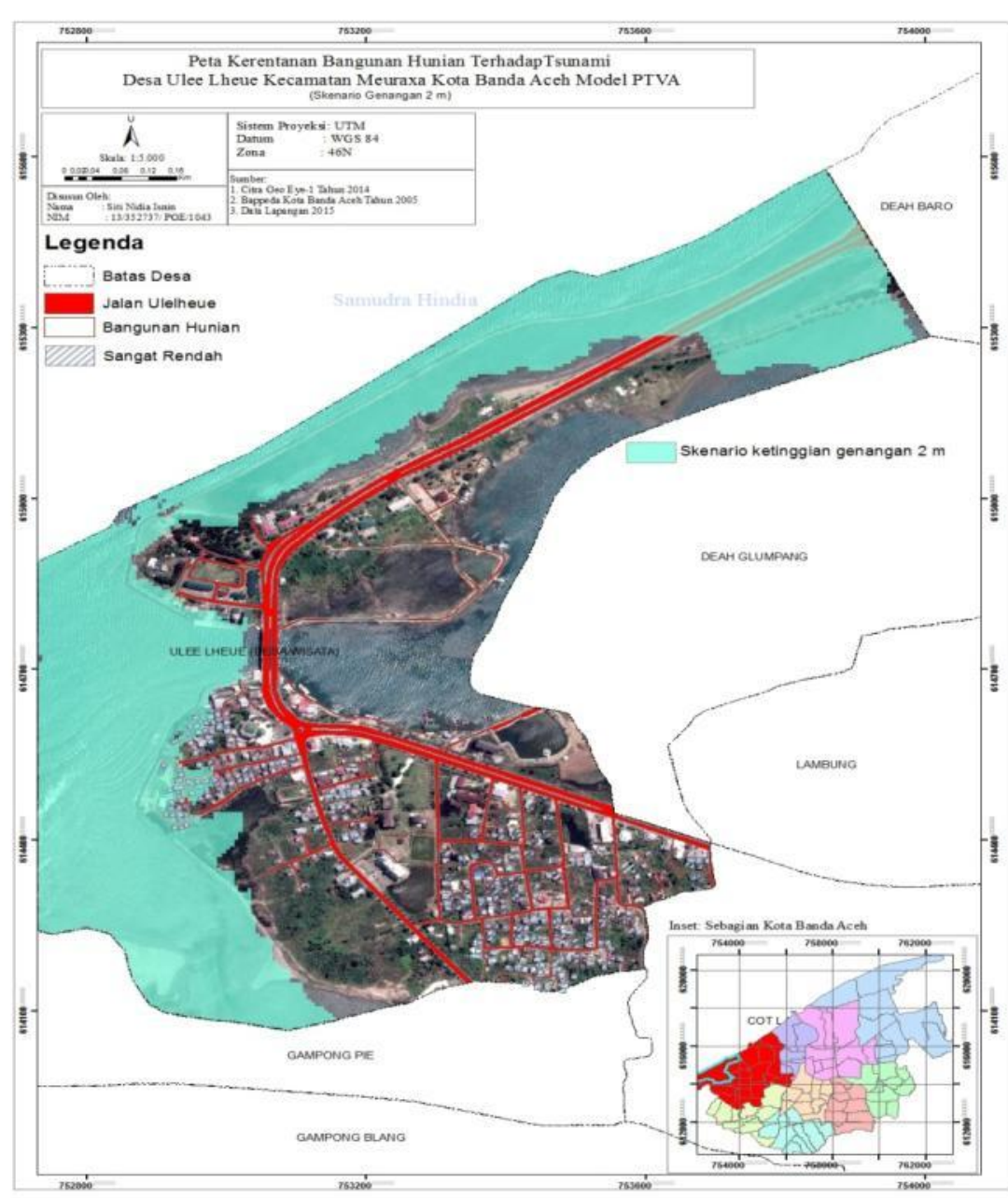

Gambar 3.2 Peta Kerentanan Bangunan Hunian Terhadap Tsunami Skenario Genangan 2m Model PTVA

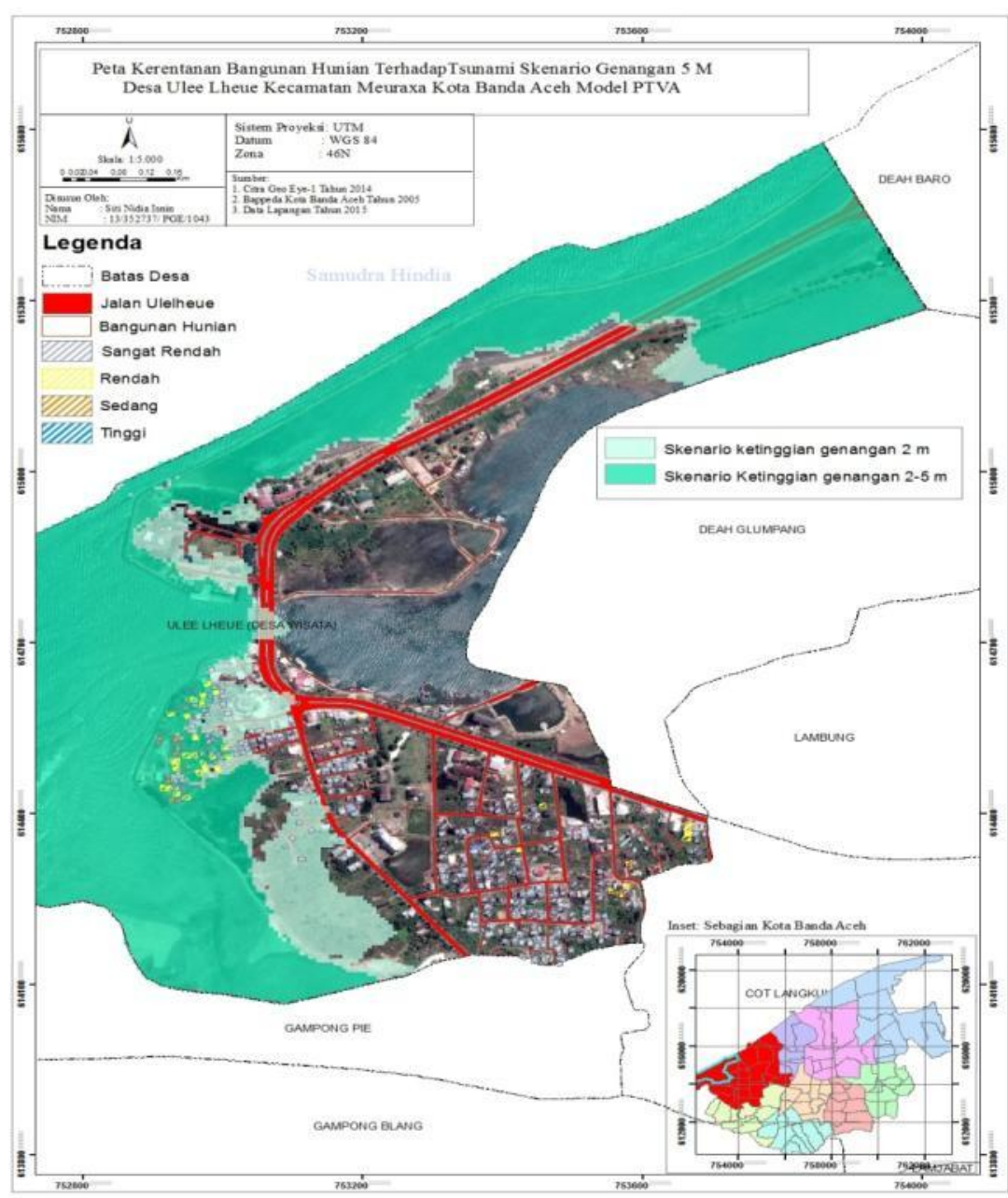

Gambar 3.3 Peta Kerentanan Bangunan Hunian Terhadap Tsunami Skenario Genangan 5m Model PTVA 


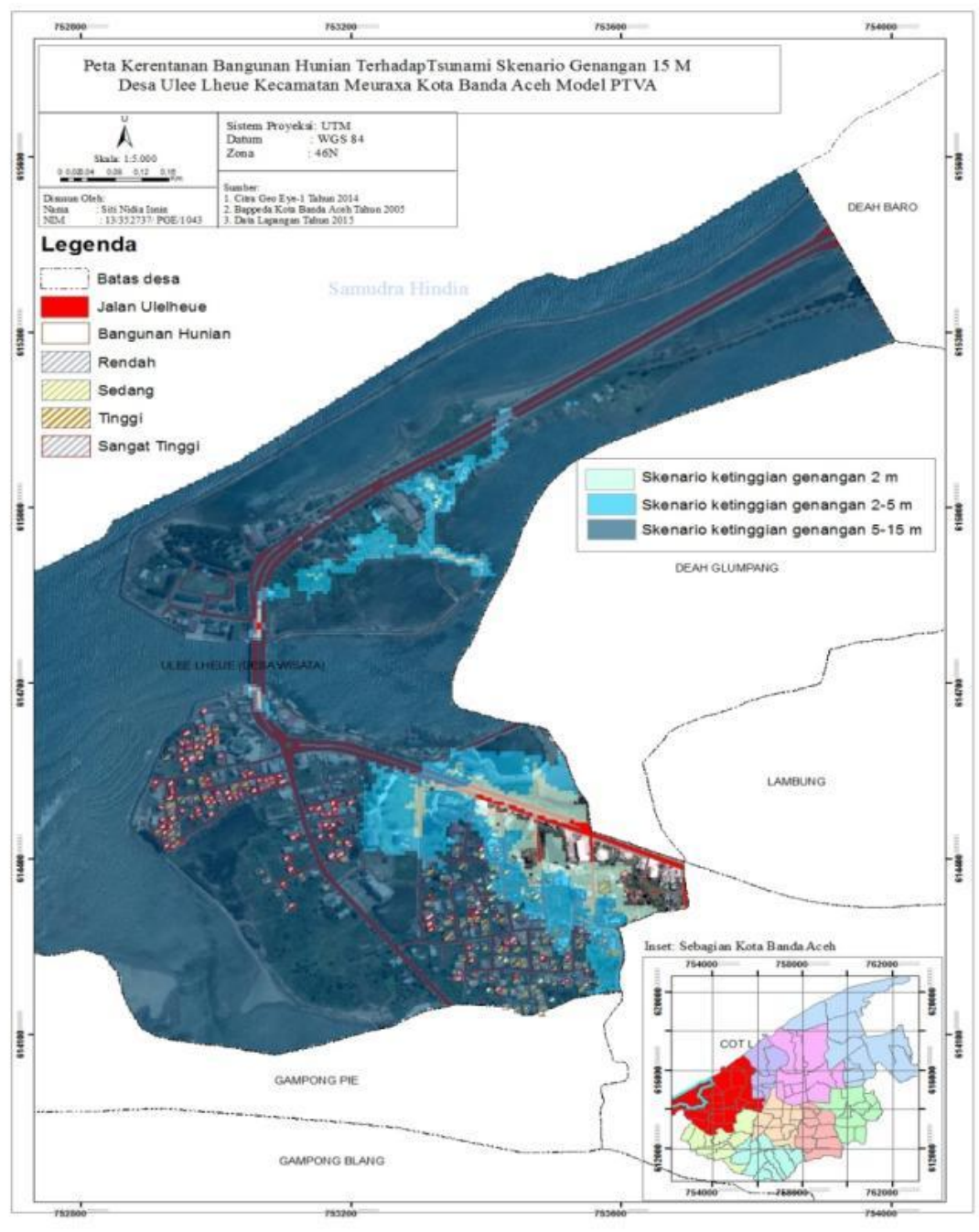

Gambar 3.4 Peta Kerentanan Bangunan Hunian Terhadap Tsunami Skenario Genangan 15m Model PTVA

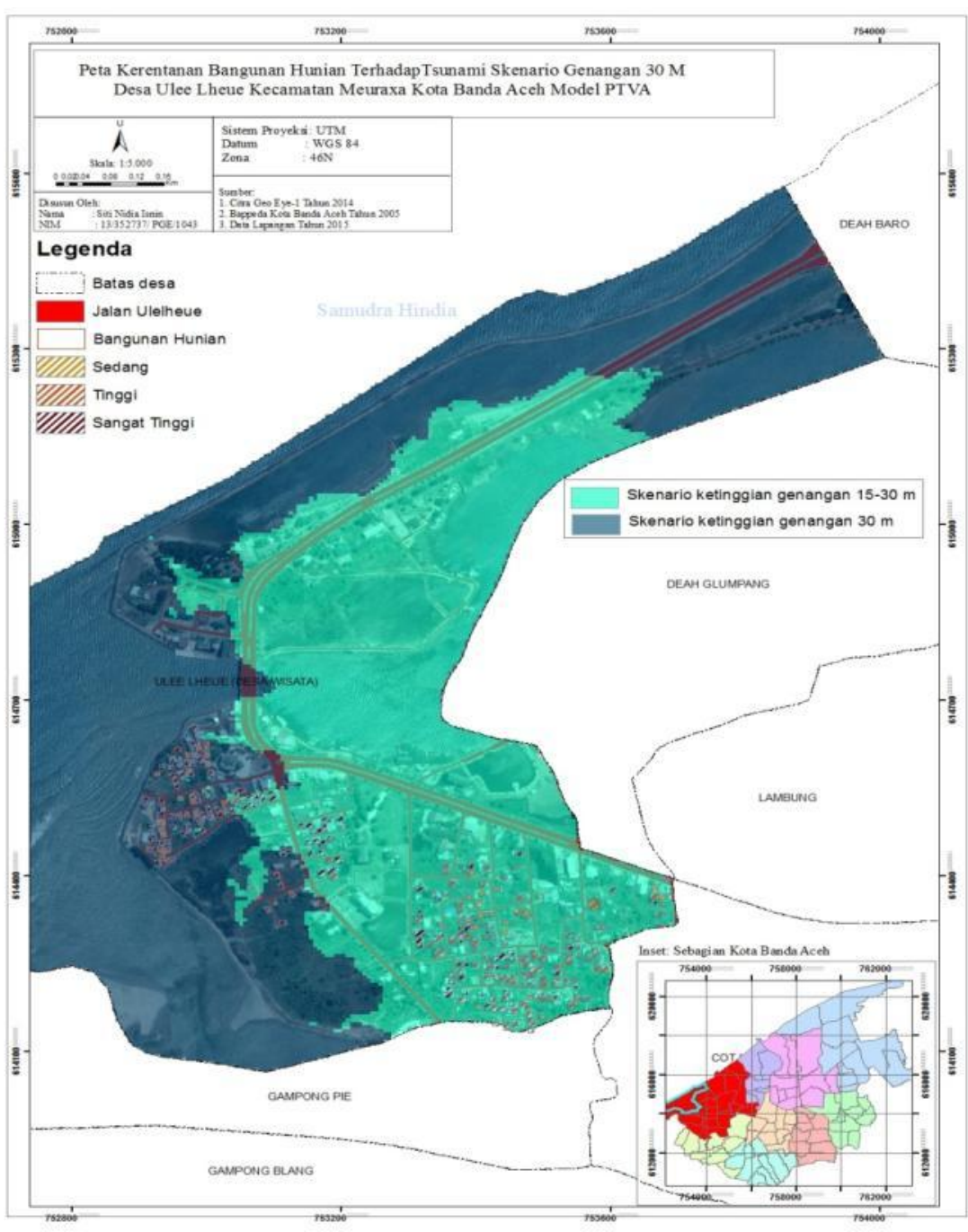

Gambar 3.5 Peta Kerentanan Bangunan Hunian Terhadap Tsunami Skenario Genangan 30m Model PTVA 


\section{Tingkat risiko bangunan terhadap tsunami \\ Risiko \\ bangunan}

berdasarkan fungsi dari

kerentanan dan harga bangunan.

Perhitungan risiko tsunami berdasarkan

dari masing-masing skenario ketinggian

gelombang. Hasil risiko dibagi menjadi lima kelas, dimulai dari kelas 1 sampai kelas 5. Tingkat risiko dinyatakan dalam kerugian secara nominal berdasarkan Nilai Jual Objek Pajak. Semakin tinggi nominalnya maka semakin tinggi tingkat kerugiannya. Tabel 4.1 menyajikan kelas risiko berdasarkan Nilai Juala Objek Pajak.

Tabel 4.1 Kelas Risiko Model PTVA

\begin{tabular}{|l|r|r|}
\hline Kelas 1 & Rp219.120 & Rp1.365.056 \\
\hline Kelas 2 & Rp1.365.056 & Rp2.510.992 \\
\hline Kelas 3 & Rp2.510.992 & Rp3.656.928 \\
\hline Kelas 4 & Rp3.656.928 & Rp4.802.864 \\
\hline Kelas 5 & Rp4.802.864 & Rp5.948.800 \\
\hline
\end{tabular}

Skenario $1 \mathrm{~m}$ dan $2 \mathrm{~m}$, tingkat risikonya memiliki tiga kelas. kelas 1 terdapat 278 bangunan hunian, kelas 2 terdapat 20 bangunan hunian dan kelas 3 terdapat 2 bangunan. Skenario $5 \mathrm{~m}$, termasuk dalam tiga kelas, yaitu kelas 1 terdapat 250 bangunan, kelas 2 terdapat 40 bangunan dan kelas 3 terdapat 10 bangunan. Skenario 15 meter dan 30 meter memiliki lima kelas dimulai dari kelas 1 sampai kelas 5 . Kelas 1 pada skenario 15 meter terdapat 62 bangunan hunian, kelas 2 terdapat 105 bangunan hunaian, kelas 3 terdapat 82 bangunan, kelas 4 tedapat 33 bangunan dan kelas 5 terdapat 18 bangunan. Kelas 1 pada skenario $30 \mathrm{~m}$ terdapat 62 bangunan, kelas 2 tedapat 102 bangunan, kelas 3 terdapat 80 bangunan. Pada skenario $1 \mathrm{~m}$ sampe $5 \mathrm{~m}$ mayoritas bangunan dikelas 1. Skenario $15 \mathrm{~m}$ dan $30 \mathrm{~m}$ mayoritas bangunan pada kelas 2 . Sehingga jika tingkat risiko ddeskripsikan dengan kata, tingkat risiko dari skenario 1 meter hingga 30 meter berada pada kelas sangat rendah dan rendah. Tingkat risiko model PTVA juga disajikan dalam bentuk tabel, dapat dilihat pada Tabel 4.2.

Tabel 4.2 Tingkat Risiko Model PTVA

\begin{tabular}{|l|r|r|r|r|l|}
\hline Skenario & Kelas 1 & Kelas 2 & Kelas 3 & Kelas 4 & Kelas 5 \\
\hline $1 \mathrm{~m}$ & 278 & 20 & 2 & - & - \\
\hline $2 \mathrm{~m}$ & 278 & 20 & 2 & - & - \\
\hline $5 \mathrm{~m}$ & 250 & 40 & 10 & - & - \\
\hline $15 \mathrm{~m}$ & 62 & 105 & 82 & 33 & 18 \\
\hline $30 \mathrm{~m}$ & 62 & 102 & 80 & 36 & 20 \\
\hline
\end{tabular}




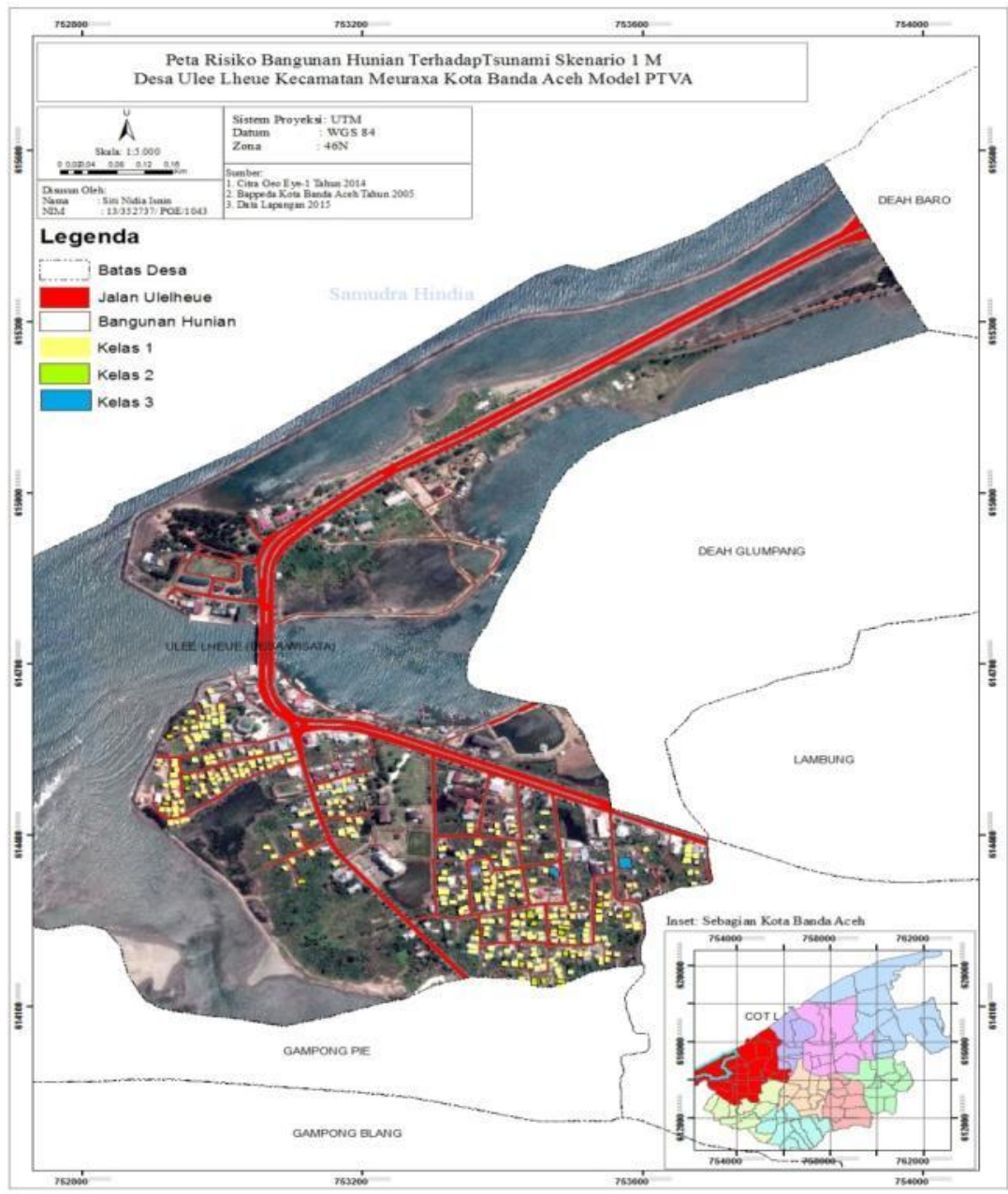

Gambar 4.35 Peta Risiko Bangunan Hunian Terhadap Tsunami Skenario Genangan 1m Model PTVA

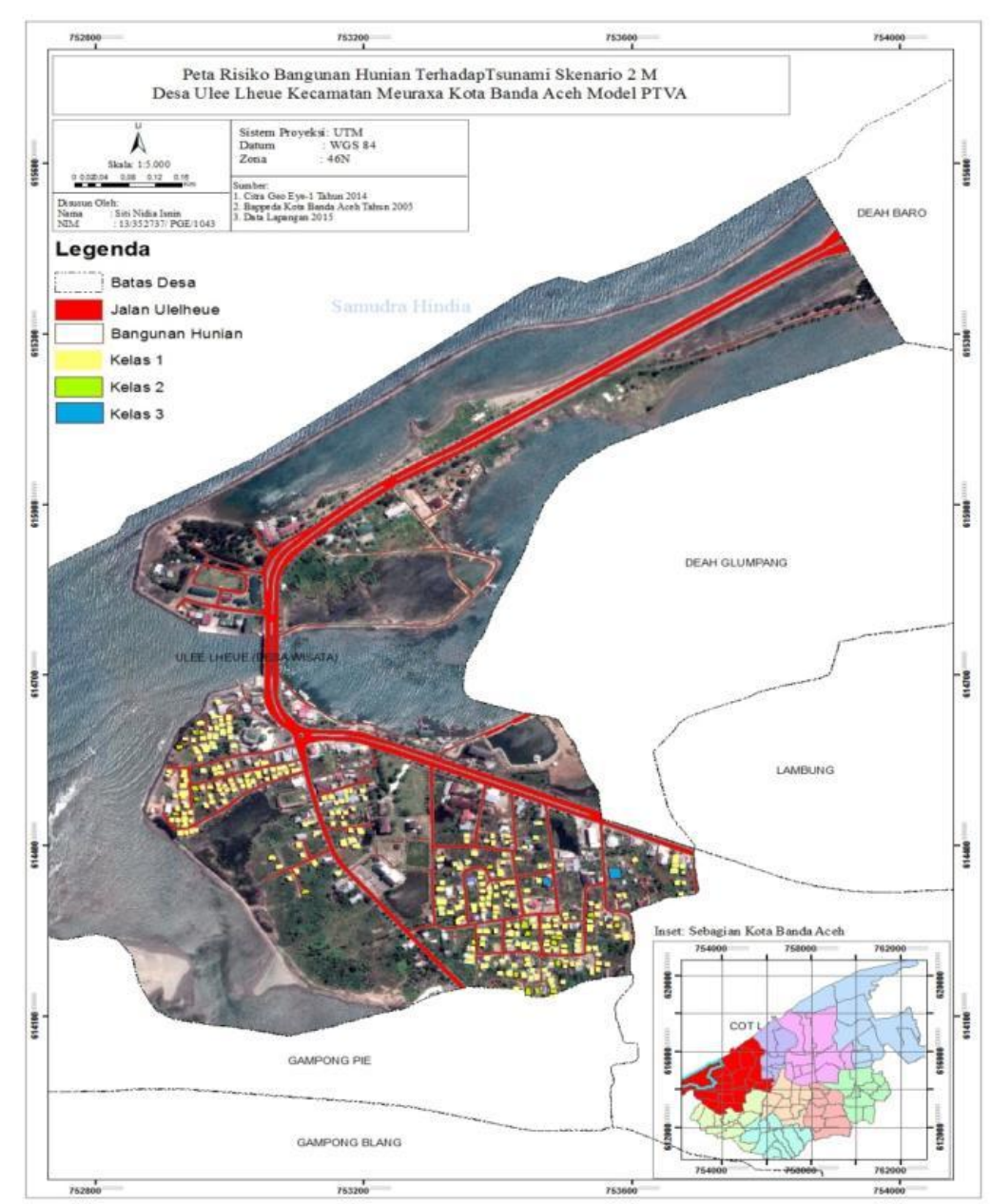

Gambar 4.36 Peta Risiko Bangunan Hunian Terhadap Tsunami Skenario Genangan 2m Model PTVA 


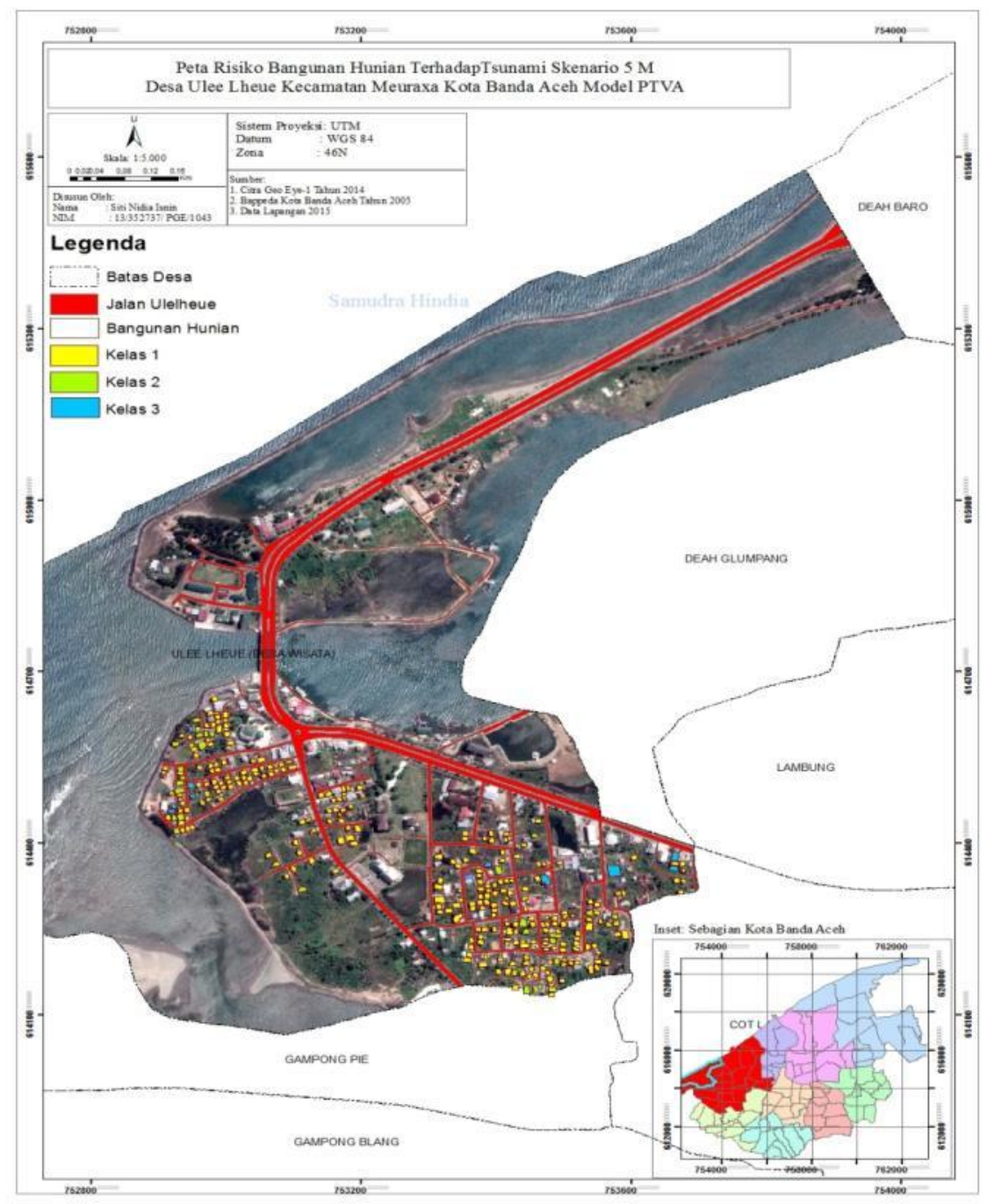

Gambar 4.37 Peta Risiko Bangunan Hunian Terhadap Tsunami Skenario Genangan 5m Model PTVA 


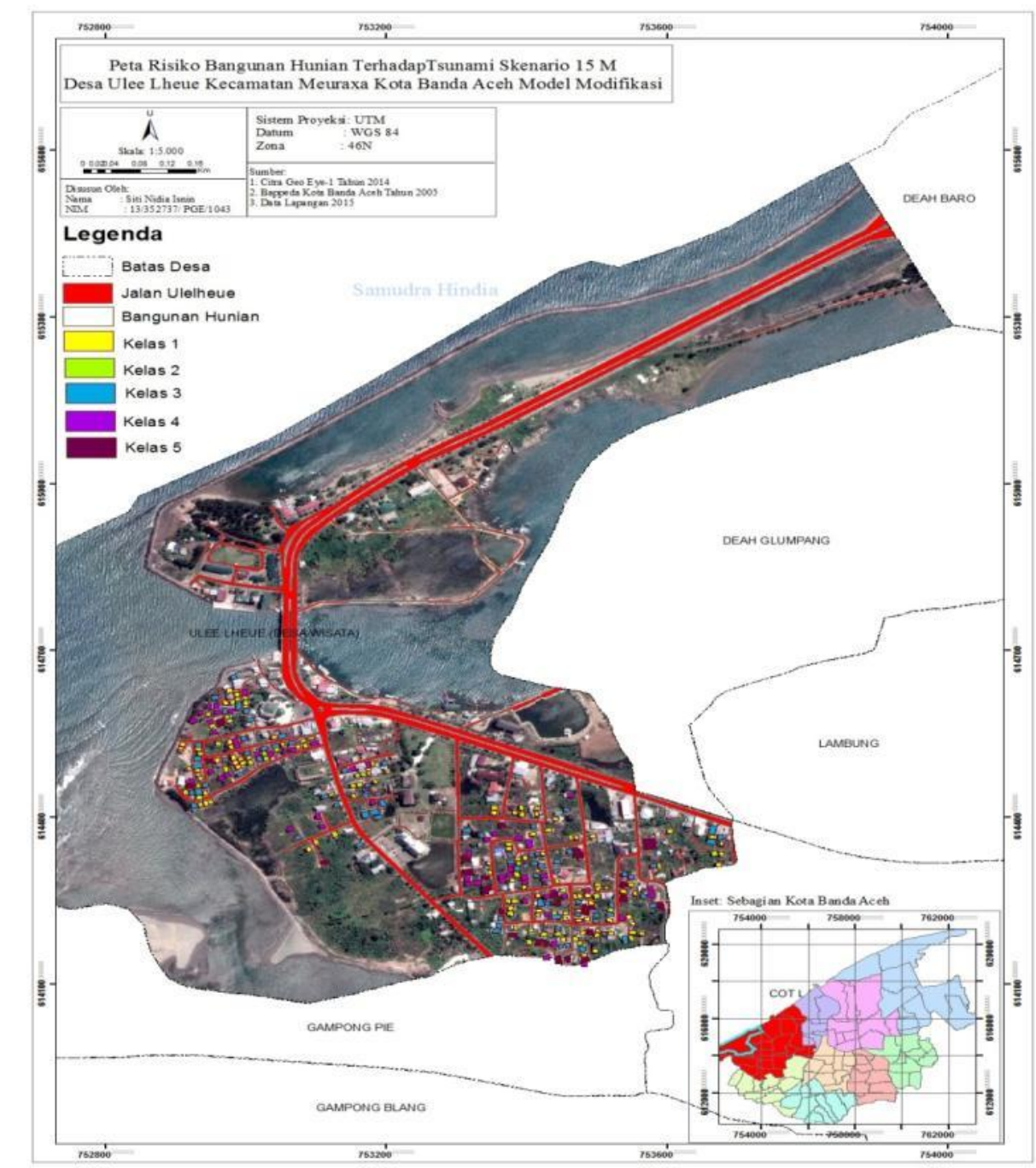

Gambar 4.38 Peta Risiko Bangunan Hunian Terhadap Tsunami Skenario Genangan 15m Model PTVA 


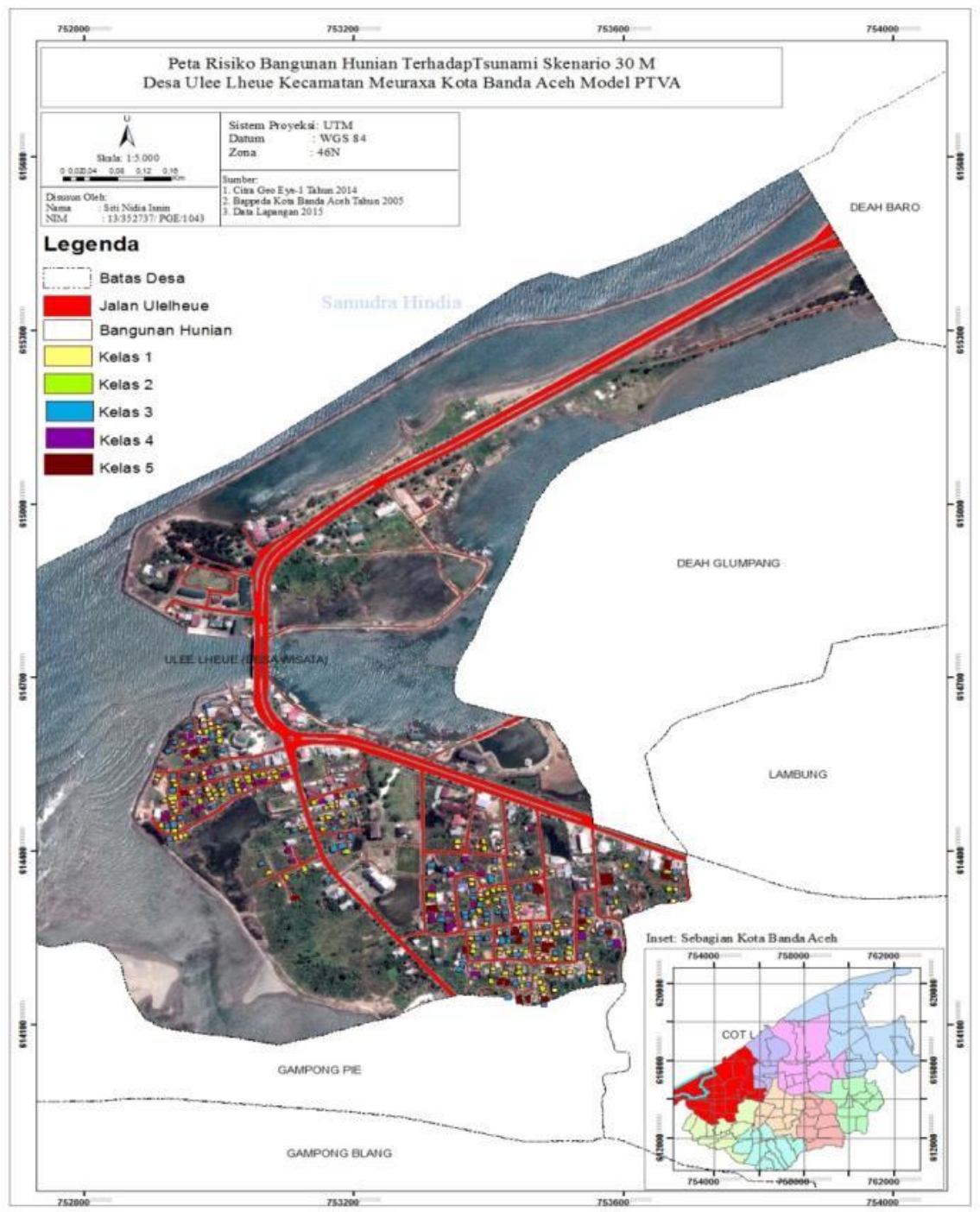

Gambar 4.39 Peta Risiko Bangunan Hunian Terhadap Tsunami Skenario Genangan 30m Model PTVA

\section{Kesimpulan}

Hasil penelitian yang telah dibahas pada bab sebelumnya dapat diberi kesimpulan sebagai berikut:

1. Selama 107 tahun dari Tahun 1907-2014 telah terjadi 4 kali kejadian tsunami. Berdasarkan data tersebut, diketahui probalitias kejadian tsunami secara random selama 100 tahun kedepan adalah
0,04 . Angka 0,04 merupakan kemungkinan yang sangat kecil, namun jika terjadi akan menimbulkan dampak yang besar. Potensi bahaya secara spasial dikelaskan menjadi 5 kelas dari kelas sangat rendah hingga kelas sangat tinggi dari masing-masing skenario. Skenario genangan 1 meter dan 2 meter berada di kelas sangat rendah, yaitu secara berurutan seluas $16.122,65 \mathrm{~m}^{2}$ dan 
$27.513,59 \mathrm{~m}^{2}$. Skenario genangan $5 \mathrm{~m}$, wilayah terluas tergenang pada kelas rendah seluas $30.298,70 \mathrm{~m}^{2}$. Skenario genangan $15 \mathrm{~m}$ wilayah terluas tergenang pada kelas sedang yaitu $59.709,87 \mathrm{~m}^{2}$. Wilayah terluas tergenang pada skenario $30 \mathrm{~m}$ seluas $66.306,49 \mathrm{~m}^{2}$. Hampir $100 \%$ wilayah tergenang pada kelas tinggi diskenario $30 \mathrm{~m}$ dari luas total wilayah yaitu $67.580,62 \mathrm{~m}^{2}$.

2. Kelas struktur bangunan dengan menggunakan model PTVA mayoritas berada pada kelas 3 , yaitu berjumlah 164 bangunan hunian dari total bangunan yaitu 300 bangunan hunian. Tingkat proteksi bangunan hunian mayoritas berada pada kelas 4 , dengan jumlah bangunan 164 dari total 300 banguna hunian. Keterpaparan bangunan terhadap tsunami berdasarkan skenarionya adalah, pada skenario $1 \mathrm{~m}$ sampai 5 $\mathrm{m}$, mayoritas bangunan berada di kelas 1, secara beurutan jumlah bangunan yang terpapar oleh tsunami adalah 286, 290 dan 232 bangunan hunian. Skenario $15 \mathrm{~m}$ dan $30 \mathrm{~m}$, mayoritas bangunan berada di kelas 5 , secara beurutan jumlah bangunan yang terpapar adalah 282 dan 300 bangunan hunian. Mayoritas Tingkat kerentanan struktur bangunan hunian di Desa Ulee Lheue model PTVA pada skenario $1 \mathrm{~m}, 2 \mathrm{~m}$ dan $5 \mathrm{~m}$ berada dari total 300 rumah, yang berada pada kelas 1 secara beurutan yaitu, 282 bangunan hunian, 287 bangunan hunian, dan 234 bangunan hunian. Skenario $15 \mathrm{~m}$ dan $30 \mathrm{~m}$, mayoritas tingkat kerentanan struktural bangunan hunian berada pada kelas 3 , yaitu 147 bangunan hunian dan 149 bangunan hunian. Indeks kerentanan relatif dari model PTVA pada skenaio $1 \mathrm{~m}$ dan $2 \mathrm{~m}$ untuk bangunan hunian di Desa Ulee Lheue seluruh bangunan yang berjumlah 300 berada pada kelas 1 atau sangat rendah. Skenario $5 \mathrm{~m}$, mayoritas bangunan berada pada kelas 1 atau sangat rendah yaitu sejumlah243 banguna dan paling sedikit berada pada kelas 4 atau tinggi sejumlah 3 bangunan hunian. Skenario $15 \mathrm{~m}$ dan $30 \mathrm{~m}$ mayoritas bangunan berada pada kelas 5 atau sangat tinggi, yaitu secara beurutan 159 dan 199 banguna hunian.

3. Tingkat risiko dari model PTVA pada skenario genangan $1 \mathrm{~m}, 2 \mathrm{~m}$ dan $5 \mathrm{~m}$ mayoritas bangunan hunian bhn erada pada kelas 1, sehingga kerugian yang ditimbulkan tiap bangunan hunian berkisar Rp. 219.120- Rp. 1.365.056. Tingkat risiko pada skenario $15 \mathrm{~m}$ dan $30 \mathrm{~m}$, mayoritas bangunan berada pada kelas 2 sehingga kerugian yang ditimbulakn berkisar $\mathrm{Rp}$ 1.365.056Rp2.510.992. 
Daftar Pustaka

Bastian, I. (2006). Valuasi Risiko Bencana. Prosiding Seminar Nasional Pelacakan Valuasi Risiko Bencana (p. 5). Yogyakarta: Pusat Studi Bencana Universitas Gadjah Mada.

Cassidy, J. F. (2015). The 2004 Sumatra Earthquake And Tsunami: Lesson Learned In Subduction Zone Science And Emergency Management For The Cascadia Subduction Zone. Pure Appl. Geophys, 835.

Dall'Osso, F., Gonella, M., Gabbianelli, G., Withycombe, G., \& Dominey, D. H. (2009). A Revised (PTVA) Model for Assessing the
Vulnerability of Buildngs to Tsunami Damage. Natural Hazard Earth System Science, 1557-1565.

Mardiatno, D., Marfa'i, M. A., Rahmawati, K., Tanjung, R., Sianturi, R. S., \& Mutiarni, Y. S. (2012). Penilaian Multirisiko Banjir Dan ROB Di Kecamatan Pekalongan Utara. Yogyakarta: RedCarpet Studio.

Zulkarnaini. (2007). Kinerja Badan Rehabilitasi Dan Rekontruksi (BRR) Dalam Pembangunan Rumah Pengungsi Korban Gempa Dan Tsunami Di Banda Aceh. Yogyakarta: Universitas Gadjah Mada. 